\title{
Clonal propagation of Eucalyptus urophylla under effect of Cyperus rotundus extract and indole-3-acetic acid
}

Propagação clonal de Eucalyptus urophylla sob efeito do extrato de Cyperus rotundus e ácido indol-3-acético

\author{
M. G. M. Santos ${ }^{1}$; W. C. Silva²; P. H. P. Ribeiro'; V. C. M. Barretto ${ }^{3}$; E. C. \\ Rocha $^{1}$; R. C. Oliveira ${ }^{4}$ J. M. Q. Luz ${ }^{4 *}$ A. S. Arruda ${ }^{1}$ \\ ${ }^{1}$ Unidade Universitária de Ipameri, Universidade Estadual de Goiás, 75780-000, Ipameri-GO, Brasil \\ ${ }^{2}$ Departamento de Agronomia, Universidade Federal dos Vales do Jequitinhonha e Mucuri, 39100-00, Diamantina- \\ MG, Brasil \\ ${ }^{3}$ Departamento de Produção Vegetal da Faculdade de Ciências Agrárias e Tecnológicas, Universidade Estadual \\ Paulista "Júlio de Mesquita Filho", 17900-000, Dracena-SP, Brasil \\ ${ }^{4}$ Instituto de Ciências Agrárias, Universidade Federal de Uberlândia, 38410-337, Uberlândia-MG, Brasil \\ *jmagno@ufu.br \\ (Received on April 02, 2021; accepted on October 06, 2021)
}

Cyperus rotondus tubers possess substances with allelopathic qualities. Some of these substances can act as synergists of plant hormones and be used for root induction in cuttings. This study aimed to shed light on the development and rooting of Eucalyptus urophylla cuttings treated with C. rotondus (nutgrass) tuber extract and IAA (indole-3-acetic acid). The experiments were conducted using a completely randomized design $\left(0 ; 25 ; 50 ; 75\right.$ and $100 \%$ nutgrass extract and $0 ; 50 ; 250 ; 500 ; 750$ and $1000 \mathrm{mg} \mathrm{L}^{-1}$ of IAA), with four repetitions per treatment and four cuttings per plot. Plantlet height, stem width and root length were measured. The greatest width and height values were recorded for the control $(0 \%$ nutgrass extract and 0 $\mathrm{mg} \mathrm{L}^{-1}$ of IAA), indicating that these substances did not contribute to the development of these variables. However, treatments of nutgrass extract up to $50 \%$ were associated with greater root length. C. rotundus extract concentrations of 53\% can be used to improve root development in E. urophylla cuttings, and contribute to the production of higher quality plantlets.

Keywords: nutgrass, plant hormone, vegetative propagation.

Os tubérculos de Cyperus rotondus (tiririca) possuem substâncias com atividade alelopática, sendo algumas destas, capazes de atuar como hormônios vegetais e ser usados na indução de raízes em estacas. Este trabalho teve como objetivo elucidar o desenvolvimento e o enraizamento de estacas de Eucalyptus urophylla tratadas com extrato de tubérculo de $C$. rotondus e AIA (ácido indol-3-acético). Os experimentos foram conduzidos em delineamento inteiramente casualizado $(0 ; 25 ; 50 ; 75$ e $100 \%$ de extrato de tiririca e $0 ; 50 ; 250 ; 500 ; 750$ e 1000 mg. $\mathrm{L}^{-1}$ de IAA), com quatro repetições por tratamento e quatro estacas por pote. As variáveis quantificadas foram altura das mudas, largura do caule e comprimento da raiz. Os maiores valores de largura e altura foram registrados na testemunha ( $0 \%$ extrato de tiririca e $0 \mathrm{mg} \mathrm{L}^{-1} \mathrm{de}$ IAA), indicando que não contribuíram para o desenvolvimento dessas variáveis. No entanto, um aumento de até 50\% no extrato de tiririca causou um aumento no comprimento da raiz, principalmente quando utilizado com $50 \mathrm{mg} . \mathrm{L}^{-1}$ de AIA. Concentrações de extrato de C. rotundus de $53 \%$ podem ser utilizadas para melhorar o desenvolvimento radicular em estacas de E. urophylla, contribuindo para a produção de mudas de melhor qualidade.

Palavras-chave: tiririca, hormônio vegetal, propagação vegetative.

\section{INTRODUCTION}

A significant percentage of lumber comes from planted forests $(46 \%)$ with the highest production in tropical and subtropical areas [1]. The impact of planted forests on natural ecosystems is controversial. Nevertheless, preserving these ecosystems requires management practices that allow producers to meet rising market demand while taking into consideration the ecological, economic and social implications throughout the entire growth process [2].

The genus Eucalyptus is found in diverse ecological settings and is valued by the bioenergy industry for its short rotation, rapid growth, superior wood properties and high adaptability to 
different climatic conditions [3, 4]. In recent years, some Eucalyptus species have gained market attention as superior sources of lignocellulosic biomass and terpenes, and for their potential in the production of high-power and high-value biofuels [5].

Eucalyptus is the most planted forest species in Brazil, [6]. Within this genus, Eucalyptus urophylla and its hybrids are the most frequently used in commercial plantations and are obtained via vegetative propagation in clonal mini-gardens that produce commercially named clones [7, 8].

Eucalyptus clonal forestry programs provide genetic gains of approximately 25 to $50 \%$, depending on how the clones are selected. In general, about 5 to 14 clones are typically used for new plantations, reaching annual average growth rates of $41 \mathrm{~m}^{3}$ per hectare per year, according to optimized clonal propagation and forest management $[9,10]$.

Despite advances in the field, the rooting of clones can be challenging and demands attention for the induction and development of adventitious roots (AR) [11]. AR is a highly complex, multilevel regulated developmental process, that is affected by several endogenous and environmental factors [12].

Plant hormones participate in this process by increasing the percentage, speed, quality and uniformity of rooting. Auxins, such as indole-3-acetic acid (IAA), are related to the hormones that are most responsible for regulating AR formation [13]. Trueman (2018) [14] emphasized the necessity of finding optimal auxin doses for increasing adventitious root numbers, since higher doses can lead to defoliation and cutting death.

Cyperus rotundus L. (nutgrass or nutsedge) can cause 20-90\% yield losses in various crops, and is considered the most significant weed worldwide [15]. Despite its negative effect on crops, nutgrass is an important medicinal plant, containing essential oils that have important compounds with antioxidant, anti-allergic, insecticidal, antimicrobial, hepatoprotective, anti-diabetic and anticonvulsant properties [16-18].

Nutgrass extract can influence some steps of plant metabolism, producing similar results to those of auxins. Allelochemicals are biochemicals produced plants that influence the development of surrounding organisms. These substances are useful in agriculture since they can improve plant growth in various ways, including the promotion of root development. These natural phytometabolites are free, environmentally friendly, biodegradable, and safe alternatives to synthetic plant growth regulators and phytohormones $[19,20]$.

IAA and Nutgrass extract have been used to stimulate rooting in various species [21-23]. Studies have shown that aqueous extracts of Cyperus rotundus tubers possess significant quantities of root promoting auxin, which is an effective root-promoting phytohormone for Prunus persica and Handroanthus chrysotrichus [24, 25]. Auxins are effective because they aid cell division and differentiation and regulate tropisms, apical dominance, root initiation and vascular tissue differentiation [26]. According to Delazeri et al. 2017 [27] despite the advantages of nutgrass extracts, related studies on eucalyptus are scarce.

Therefore, the present study aimed to assess shoot development and rooting in Eucalyptus urophylla cuttings after applications of Cyperus rotundus tuber extract and IAA.

\section{MATERIAL AND METHODS}

The experiment was carried out in a greenhouse, with lateral and overhead shading (50\%), located at the Universidade Estadual de Goiás - University Unit of Ipameri (17 $47^{\circ} 0^{\prime \prime}$ S, 48 $8^{\circ} 38^{\prime}$ " $\mathrm{W}$ and $773 \mathrm{~m}$ altitude), Ipameri, Goiás, Brazil. The region has a tropical climate with a dry winter and wet summer (Aw) (Köppen).

Clonal Eucalyptus urophylla cuttings were obtained from parent plants at a commercial nursery. The eucalyptus mini-cuttings were produced in a mini-garden, harvested at $4 \mathrm{~cm}$ (height), refrigerated with water to maintain moisture, and transported to the laboratory for planting. Cyperus rotundus extracts were obtained from fresh tubers that had been washed, dried with paper towels and weighed, using $10 \mathrm{~g}$ of tubers per $200 \mathrm{ml}$ of water. An exsicatti (dried specimen) of the plant sample was deposited in the Herbarium of Universidade Estadual de Goiás (HUEG) and registered as number 11770 . 
After processing, the samples were sieved and diluted in distilled water at the following concentrations: $0 \% ; 25 \% ; 50 \% ; 75 \%$ and $100 \%$. The extracts were prepared 24 hours before application to the cuttings and kept on ice until use. The commercial IAA concentrations used were $0 \mathrm{mg} \mathrm{L}^{-1} ; 50 \mathrm{mg} \mathrm{L}^{-1} ; 250 \mathrm{mg} \mathrm{L}^{-1} ; 500 \mathrm{mg} \mathrm{L}^{-1} ; 750 \mathrm{mg} \mathrm{L}^{-1}$ and $1000 \mathrm{mg} \mathrm{L}^{-1}$.

The mini-cuttings were submitted to the different nutgrass and IAA treatments by immersing a stalk in the extract for 1 minute. The cuttings were then planted in polypropylene tubes $\left(53 \mathrm{~cm}^{3}\right)$ containing a substrate of medium-grain vermiculite and then placed in a greenhouse with lateral and overhead shading. The temperature was monitored by thermometers $\left(\sim 25^{\circ} \mathrm{C}\right)$ and the humidity was maintained by nebulization four times a day for 25 minutes. Nebulization was suspended overnight.

A completely randomized design was used with a factorial arrangement of 5 nutgrass and 6 IAA concentrations, four repetitions per treatment in both experiments and four cuttings per plot. The cuttings were assessed 90 days after planting (DAP). The following variables were measured: plant height $(\mathrm{cm})$ and root length $(\mathrm{cm})$, measured with a ruler, and stem width $(\mathrm{cm})$, determined using a caliper.

Data were submitted to analysis of variance (ANOVA) and a means test with splits. Afterwards, polynomial or linear regression analysis was used to assess the effects of the nutgrass and IAA doses. All statistical analyses were performed using Sisvar v.5.6. software [28].

\section{RESULTS AND DISCUSSION}

Clonal propagation of Eucalyptus urophylla can be optimized by applications of Cyperus rotundus tubercle extract and exogenous auxin (IAA), used either alone or in combination, to enhance the rooting of mini-cuttings. The propagules that did not receive applications of nutgrass extracts and/or IAA did not root within the time period of the experiment. The lowest concentrations of nutgrass extract and IAA produced the best rooting, while higher concentrations, greater than $70 \%$ for nutgrass extract and $500 \mathrm{mg} \mathrm{L}^{-1}$ for IAA, reduced rooting in correlation with rising doses.

The results indicated that nutgrass tuber extracts and IAA had a significant effect $(\mathrm{p}<0.05)$ on stem height and diameter and root length. However, the interaction between the two did not significantly affect $(\mathrm{p}>0.05)$ seedling height (Table 1$)$. The means test showed that rooting was optimized by combinations of low doses of IAA (between 50 and $250 \mathrm{mg} \mathrm{L}^{-1}$ ) and nutgrass extract (from $25 \%$ to $50 \%$ ). The combination of IAA $50 \mathrm{mg} \mathrm{L}^{-1}$ and nutgrass extract $50 \%$ produced roots that were $32 \%$ greater than those produced by IAA $50 \mathrm{mg} \mathrm{L}^{-1}$ in isolation. The effect was a $12 \%$ increase in stem height. Stem diameter was not significantly affected by the various applications, but in general, the smallest diameters were found in the treatments with the highest concentrations.

While some studies have shown that nutgrass extract increases rhizogenesis, and other studies have looked at combinations of the extract and various hormones, none have looked at interactions between nutgrass extract and IAI. The positive effect of nutgrass extract on plant growth has also never been explained. One study showed that the root length of Duranta repens cuttings was approximately $5 \%$ greater than it was with applications of $500 \mathrm{mg} \mathrm{L}^{-1} \mathrm{IBA}$; however, the number of roots was $15 \%$ greater than with IBA [29]. Thiesen et al. (2019) [26] studied grapevine cuttings and found that nutgrass extract promoted root elongation to the same degree as AIB and ANA. Another study examined the effect of nutgrass extract alone on Handroanthus chrysotrichus cuttings, and found that the cuttings that remained immersed in 50\% extract had $31.7 \%$ and $40 \%$ higher rooting rate and root compliance, respectively, than did the control (without extract exposure) [25].

Enhanced root development at low doses of IAA and nutgrass extracts may be associated with the presence of phenolic acids that act as growth regulators and inhibit auxin oxidases and prevent the degradation of IAA in cuttings [30]. A phytochemical characterization of Cyperus rotundus showed the presence of two bioactive phenolic compounds, quercetin and chlorogenic acid, which can act as non-hormonal plant regulators [31]. 
Table 1: Analysis of variance and means test of the effects of Cyperus rotundus extract concentrations and IAA doses on the cutting height and diameter and root length Eucalyptus urophylla cuttings.

\begin{tabular}{|c|c|c|c|c|c|c|c|}
\hline \multirow[b]{2}{*}{$\mathrm{FV}$} & \multicolumn{2}{|c|}{ Height $(\mathrm{cm})$} & \multicolumn{2}{|c|}{ Diameter $(\mathrm{cm})$} & \multicolumn{2}{|c|}{ Root $(\mathrm{cm})$} & \\
\hline & QM & $\mathrm{P}$ & $\mathrm{QM}$ & $\mathrm{P}$ & $\mathrm{QM}$ & $\mathrm{P}$ & \\
\hline Extract & 19.12 & 0.01 & 0.013 & 0.00 & 48.44 & 0.03 & \\
\hline IAA & 68.97 & 0.00 & 0.056 & 0.00 & 118.75 & 0.00 & \\
\hline Extract $x$ IAA & 6.53 & 0.29 & 0.004 & 0.01 & 59.01 & 0.00 & \\
\hline Residual & 5.54 & & 0.002 & & 17.68 & & \\
\hline CV\% & 26.23 & & 3.8 & & 47.7 & & \\
\hline \multirow{9}{*}{ 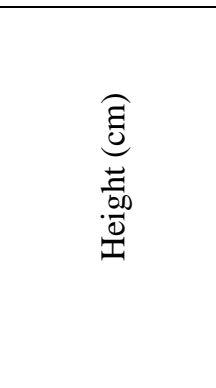 } & \multicolumn{6}{|c|}{ Extract $(\%)$} & \\
\hline & IAA $(\mathrm{mg} / \mathrm{L})$ & 0 & 25 & 50 & 75 & 100 & $\bar{x}$ IAA \\
\hline & 0 & 10.91 & 10.7 & 11.1 & 10.0 & 5.87 & $9.71 \mathrm{~B}$ \\
\hline & 50 & 11.66 & 12.3 & 12.39 & 12.61 & 10.67 & $11.9 \mathrm{~A}$ \\
\hline & 250 & 11.64 & 11.01 & 10.7 & 8.1 & 7.38 & $9.76 \mathrm{~B}$ \\
\hline & 500 & 7.83 & 8.0 & 6.31 & 6.81 & 5.4 & $6.87 \mathrm{C}$ \\
\hline & 750 & 7.71 & 6.79 & 6.15 & 8.39 & 9.29 & $7.67 \mathrm{C}$ \\
\hline & 100 & 9.29 & 7.53 & 8.1 & 8.18 & 6.25 & $7.87 \mathrm{C}$ \\
\hline & $\bar{x}$ nutgrass & $9.81 \mathrm{a}$ & $9.39 \mathrm{a}$ & $9.12 \mathrm{a}$ & $9.01 \mathrm{a}$ & $7.47 \mathrm{~b}$ & \\
\hline \multirow{8}{*}{ 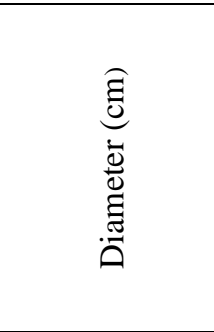 } & \multicolumn{6}{|c|}{ Extract $(\%)$} & \\
\hline & IAA $(\mathrm{mg} / \mathrm{L})$ & 0 & 25 & 50 & 75 & 100 & \\
\hline & 0 & $1.4 \mathrm{aA}$ & $1.35 \mathrm{aA}$ & $1.38 \mathrm{aA}$ & $1.32 \mathrm{bB}$ & $1.26 \mathrm{aB}$ & \\
\hline & 50 & $1.4 \mathrm{aA}$ & $1.36 \mathrm{bA}$ & $1.37 \mathrm{bA}$ & $1.46 \mathrm{aA}$ & $1.34 \mathrm{bA}$ & \\
\hline & 250 & $1.38 \mathrm{aA}$ & $1.35 \mathrm{aA}$ & $1.38 \mathrm{aA}$ & $1.31 \mathrm{bB}$ & $1.3 \mathrm{bA}$ & \\
\hline & 500 & $1.31 \mathrm{aB}$ & $1.27 \mathrm{aB}$ & $1.23 \mathrm{aB}$ & $1.29 \mathrm{aB}$ & $1.31 \mathrm{aB}$ & \\
\hline & 750 & $1.33 \mathrm{aB}$ & $1.31 \mathrm{aA}$ & $1.24 \mathrm{bB}$ & $1.24 \mathrm{bB}$ & $1.29 \mathrm{aA}$ & \\
\hline & 100 & $1.26 \mathrm{aB}$ & $1.24 \mathrm{aB}$ & $1.23 \mathrm{aB}$ & $1.25 \mathrm{aB}$ & $1.21 \mathrm{aB}$ & \\
\hline \multirow{8}{*}{ 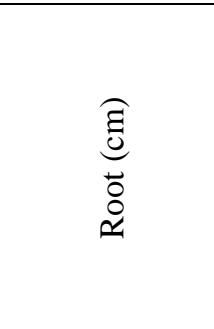 } & \multicolumn{6}{|c|}{ Extract $(\%)$} & \\
\hline & IAA $(\mathrm{mg} / \mathrm{L})$ & 0 & 25 & 50 & 75 & 100 & \\
\hline & 0 & $0.0 \mathrm{bB}$ & $9.98 \mathrm{aB}$ & $12.58 \mathrm{aB}$ & $9.77 \mathrm{aA}$ & $3.2 \mathrm{bB}$ & \\
\hline & 50 & $12.63 \mathrm{bA}$ & $13.32 \mathrm{bA}$ & $18.59 \mathrm{aA}$ & $12.72 \mathrm{bA}$ & $7.67 \mathrm{bB}$ & \\
\hline & 250 & $11.59 \mathrm{aA}$ & $14.07 \mathrm{aB}$ & $13.61 \mathrm{aA}$ & $6.76 \mathrm{bB}$ & $4.98 \mathrm{bB}$ & \\
\hline & 500 & $7.07 \mathrm{aA}$ & $8.52 \mathrm{aB}$ & $4.6 \mathrm{aB}$ & $8.21 \mathrm{aA}$ & $3.28 \mathrm{aA}$ & \\
\hline & 750 & $6.93 \mathrm{bA}$ & $6.72 \mathrm{bB}$ & $2.04 \mathrm{bB}$ & $10.76 \mathrm{aA}$ & $12.1 \mathrm{aA}$ & \\
\hline & 100 & $12.15 \mathrm{aA}$ & $6.59 \mathrm{aB}$ & $6.91 \mathrm{aB}$ & $9.26 \mathrm{aA}$ & $7.7 \mathrm{aA}$ & \\
\hline
\end{tabular}

Lower case letters within the same row and uppercase letters with the same column do not differ by the means test at $5 \%$ probability.

Regression analysis was used to assess the effect of the nutgrass concentrations and showed decreasing linear behavior for plantlet height $\left(R^{2}=0.61 ; p=0.043\right)$ and stem width $\left(R^{2}=0.84 ; p\right.$ $=0.002)$ and quadratic behavior for root length $\left(\mathrm{R}^{2}=0.99 ; \mathrm{p}=0.000\right)$ (Figure 1).

Plantlet height and stem width showed similar behavior in relation to the nutgrass concentrations used (Figures 1A and 1B). The highest values for these variables were observed at the lowest concentrations of the extract, indicating that the extract did not contribute to height or width. The 50\% nutgrass dose increased root length, whereas higher doses did not (Figure 1C).

There is still a lack of consensus regarding the importance of nutgrass extract on promoting plantlet rooting. In this respect, Dias et al. (2012) [32] analyzed rooting in coffee plant cuttings immersed in aqueous nutgrass extract and suggested it was not a viable rooting alternative. Coltro et al. (2011) [33] studied the rooting of IAC 313 grapevine rootstock cuttings in nutgrass extract and concluded that the cuttings treated with $1 \%$ extract resulted in more roots per cutting and fewer cuttings without roots. The aqueous nutgrass extract was efficient at promoting rhizogenesis and produced a similar rooting percentage to that observed for AIB solution $\left(1000 \mathrm{mg} \mathrm{L}^{-1}\right)$ in Solanum lycopersicum L. leaves [34].

The stimulatory effect of exogenous auxins on roots (synthetic or from plant extracts) depends on the concentration applied to the base of the cutting, where root stimulation increases up to a maximum dose, after which any additional increases are inhibitory [14, 35]. The effect also depends on the composition of the phenolic compounds as they are transferred to the plantlets, 
and how interactions of these metabolites with auxin and peroxidases affect the formation of adventitious roots. Phenolics are also important in modulating peroxidase activity and can also act as antioxidants, preventing auxin degradation at the base of the cuttings [36]. In the present study, nutgrass extract showed an inhibitory effect at the 53\% concentration (Figure 1C).
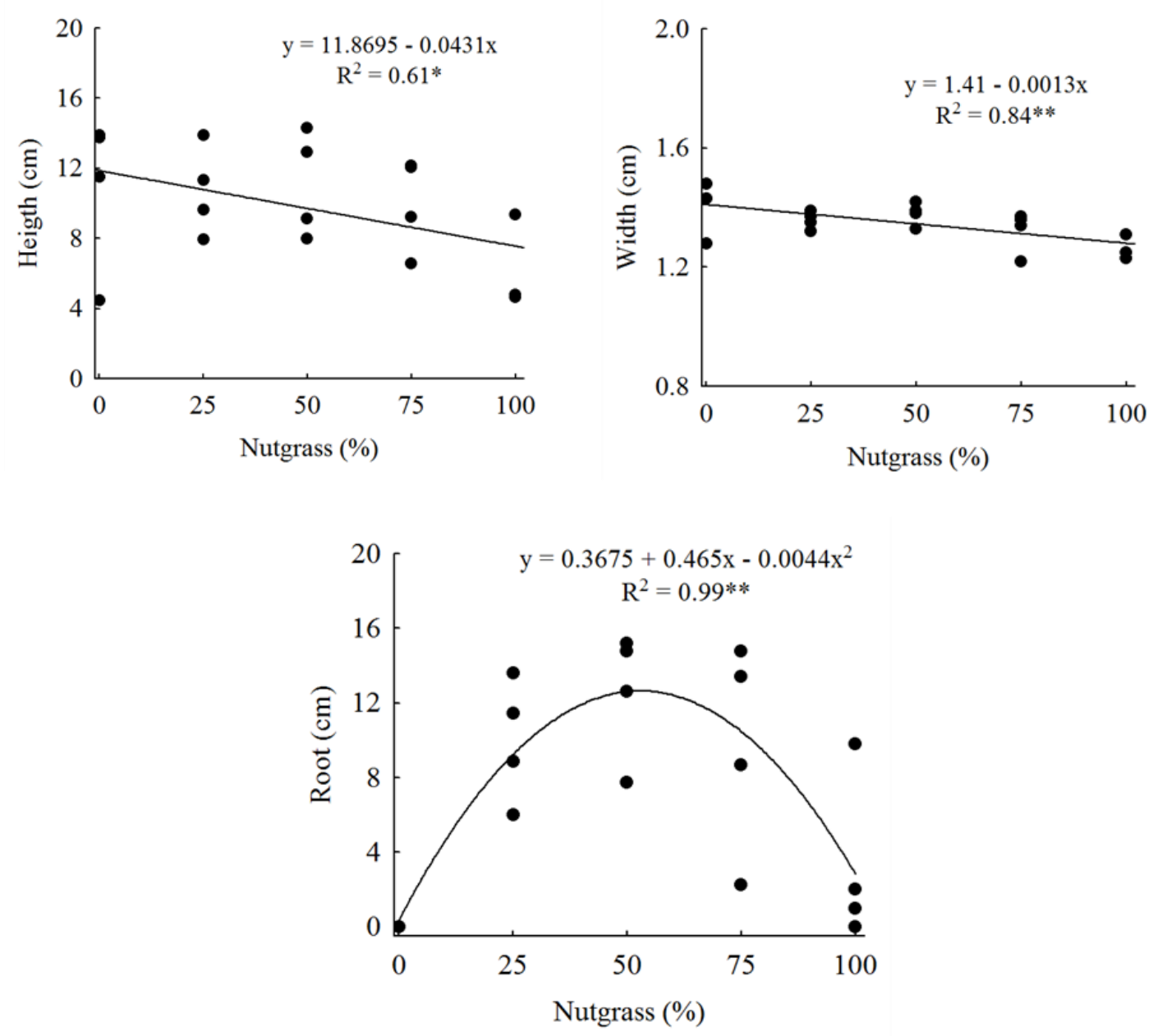

Figure 1: Regression analysis of the effect of Cyperus rotundus extract on the variables studied. Effect of C. rotundus extract on $(A)$ plantlet height, $(B)$ stem width and $(C)$ root length. Legend: * significant regression $(0.01<p \leq 0.05) ; * *=$ significant regression $(p \leq 0.01)$.

Regression analysis of the effect of IAA demonstrated a linear decline for plantlet height $\left(\mathrm{R}^{2}\right.$ $=0.52 ; p=0.026)$ and stem width $\left(R^{2}=0.90 ; p=0.001\right)$ and nonsignificant regression $(p>0.05)$ for root length. The highest values for plantlet height and stem width were obtained in the absence of IAA (Figure 2). An increase in IAA concentration had no effect on these variables (Figure 2A and $2 \mathrm{~B})$. 

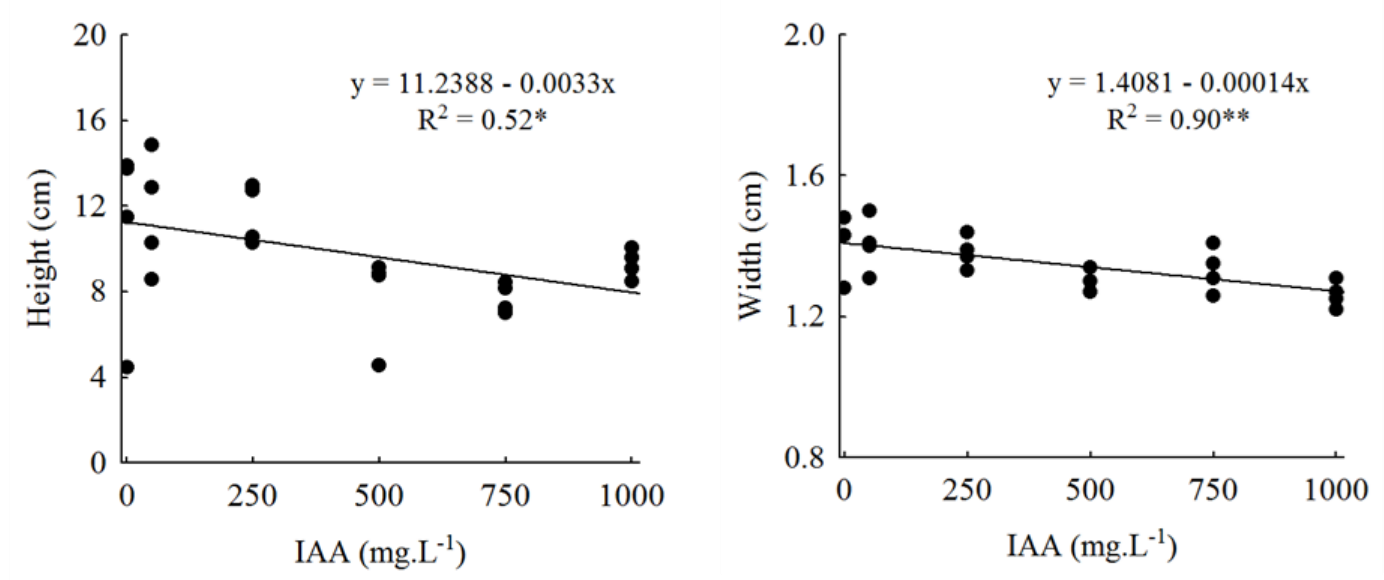

Figure 2: Regression analysis of the effect of IAA on the variables studied. Effect of IAA on (A) plantlet height, and $(B)$ stem width. Legend: $*=$ significant regression $(0.01<p=0.05)$; $* *=$ significant regression $(p=0.01)$.

Use of an exogenous auxin can promote root formation provided sufficient quantities are supplied [37]. This generally does not occur since, according to Negishi et al. (2014) [21], IAA is relatively unstable, despite being the primary endogenous auxin.

In a study on the effects of the plant growth regulators IBA and NAA on adventitious rooting in mini-cuttings of four Eucalyptus grandis x E. urophylla clones, Goulart et al. (2008) [38] found that the cuttings responded more efficiently to IBA than to NAA. IBA doses greater than $500 \mathrm{mg}$ $\mathrm{L}^{-1}$ were more efficient in all four clones, whereas a degree of toxicity was observed in some clones at concentrations at or above $2000 \mathrm{mg} \mathrm{L}^{-1}$. Scariot et al. (2017) [24] evaluated the effect of an aqueous extract of $C$. rotundus and IAA on hardwood peach cuttings and found greater rooting at $500 \mathrm{mg} \mathrm{L}^{-1}$ of IAA, but no improvement in rooting from nutgrass.

Câmara et al. (2016) [39] reported positive influences on the survival and sprouting rates of mini-cuttings of acerola with $C$. rotundus applications. Silva et al. (2011) [40] also detected beneficial results using $C$. haspan for rooting sugarcane. Azevedo et al. (2020) [41] evaluated $C$. haspan extract on coffee plants and found improvements when the extract was associated with humic acid, which may have resulted from the combined effect of the auxins present in both the humic acid and extract.

Delazeri et al. 2017 [27] evaluated applications of violet (S. ionantha) and nutgrass $(C$. rotundus) on $E$. dunnii and $E$. badjensis and reported that the species respond differently to the application of phytohormones and that more study was needed to find optimal species and doses. The authors also emphasized that natural phytohormones induce rooting, which leads to better survival rates in Eucalyptus cuttings.

\section{CONCLUSION}

Cyperus rotundus extract concentrations of $53 \%$ can be used to improve root development in E. urophylla cuttings, which contributes to higher quality plantlets. An IAA concentration of 50 $\mathrm{mg} \mathrm{L}^{-1}$ was the most beneficial for rooting. This benefit was even greater when combined with optimal doses of nutgrass extract.

Plant extracts show promising results and may be more effective than commercially available synthetic options. The findings of the current study underscore the impact and relevance of studies on plant extracts that shed light on the behavior of species and potential extracts, the use of naturally occurring resources and leveraging synergies within these systems. 


\section{ACKNOWLEDGEMENTS}

The authors acknowledge the following institutions for their assistance: The Universidade Estadual de Goiás - UEG / Unidade de Ipameri and Universidade Federal de Uberlândia - Campus Umuarama.

\section{REFERENCES}

1. Manca A, da Silva MR, Guerrini IA, Fernandes DM, Villas Bôas RL, da Silva LC, et al. Composted sewage sludge with sugarcane bagasse as a commercial substrate for Eucalyptus urograndis seedling production. J Clean Prod. 2020 Oct;269(122145):1-10. doi: 10.1016/j.jclepro.2020.122145

2. Bayle G. Ecological and social impacts of Eucalyptus tree plantation on the environment. JBCBM. 2019 Jul;5(1):93-104. doi: 10.3329/jbcbm.v5i1.42189

3. Leonardi GA, Carlos NA, Mazzafera P, Balbuena TS. Eucalyptus urograndis stem proteome is responsive to short-term cold stress. Genet Mol Biol. 2015 Apr;38(2):191-8. doi: 10.1590/S1415475738220140235

4. Dasgupta MG, Burragoni S, Amrutha S, Muthupandi M, Parveen ABM, Sivakumar V, et al. Diversity of bacterial endophyte in Eucalyptus clones and their implications in water stress tolerance. Microb Res. 2020 Dec;241:126579. doi: 10.1016/j.micres.2020.126579

5. Davis MR, Kainer D, Tuskan GA, Langholtz MH, Hellwinckel CM, Shedden M, et al. Modeled economic potential for Eucalyptus spp. production for jet fuel additives in the United States. Biomass and Bioenerg. 2020 Dec;143:105807. doi: 10.1016/j.biombioe.2020.105807

6. Bassaco MVM, Motta ACV, Pauletti V, Prior SA, Nisgoski S, Ferreira CF. Nitrogen, phosphorus, and potassium requirements for Eucalyptus urograndis plantations in southern Brazil. New Forest. 2018 Sep;49:681-97. doi: 10.1007/s11056-018-9658-0

7. Simetti R, Bonduelle GM, Silva DA, Mayer SLS, Souza HP, Muniz GIB. Production of biomass and energy stock for five Eucalyptus species. Braz J Wood Sci. 2018 Feb;9(1):30-6. doi: 10.12953/21776830/rcm.v9n1p30-36

8. Cerveira Junior WR, da Costa YKS, Carbonari CA, Duke SO, Alves PLCA, de Carvalho LB. Growth, morphological, metabolic and photosynthetic responses of clones of Eucalyptus to glyphosate. Forest Ecol Manag. 2020 Aug;470:118218. doi: 10.1016/j.foreco.2020.118218

9. de Almeida MR, Aumond M, da Costa CT, Schwambach J, Ruedell CM, Correa LR, et al. Environmental control of adventitious rooting in Eucalyptus and Populus cuttings. Tree. 2017 Oct;31(5):1377-90. doi: 10.1007/s00468-017-1550-6

10. Wu HX. Benefits and risks of using clones in forestry - a review. Scand J For Res. 2018 Jun;34(5):1-8. doi: $10.1080 / 02827581.2018 .1487579$

11. Prado ZD, Oliveira SL, Okino-Delgado CH, Auer S, Ludwig-Müller J, Silva MR, et al. Aspergillus flavipes as a novel biostimulant for rooting-enhancement of Eucalyptus. J Clean Prod. 2019 Oct;234:681-9. doi: 10.1016/j.jclepro.2019.06.211

12. Vilasboa J, da Costa CT, Fett-Neto AG. Rooting of eucalypt cuttings as a problem-solving oriented model in plant biology. Prog Biophys Mol Biol. 2018 Sep;146:85-97. doi: 10.1016/j.pbiomolbio.2018.12.007

13. Lakehall A, Chaabouni S, Cavel E, Le Hir R, Ranjan A, Raneshan Z, et al. A molecular framework for the control of adventitious rooting by the TIR1/AFB2-Aux/IAA-dependent auxin signaling in Arabidopsis. Mol Plant. 2019 Nov;4(12):1499-514. doi:10.1016/ j.molp.2019.09.001

14. Trueman SJ. Cytokinin and auxin effects on survival and rooting of Eucalyptus pellita and E. grandis $\times$ E. pellita cuttings. Rhizosphere, 2018 Jun;6:74-76. doi:10.1016/j.rhisph.2018.04.001

15. Peerzada AM. Biology, agricultural impact, and management of Cyperus rotundus L.: the world's most tenacious weed. Acta Physiol Plant. 2017 Nov;39(270):1-14. doi: 10.1007/s11738-017-2574-7

16. Thorat BR, Sabiha K, Mrunali M. Review on medicinally important Weed - Cyperus rotundus L. RJST, 2018 Oct;10(4):300-322. doi:10.5958/2349-2988.2018.00042.6

17. Ahmed Z. Nut grass: A plant with significant medicinal values. J Pharmacogn Phytochem. 2019 Aug; $8(5): 1042-5$.

18. Simorangkir D, Masfria M, Harahap U, Satria D. Activity Anticancer n-hexane fraction of Cyperus Rotundus L. rhizome to breast cancer MCF-7 cell line. Open Access Maced J Med Sci. 2019 Nov;7(22):3904-6. doi: 10.3889/oamjms.2019.530

19. El-Sherif F. Aloe vera leaf extract as a potential growth enhancer for Populus trees grown under in vitro conditions. Am J Plant Biol. 2017 Jul;2(3):101-5. doi: 10.11648/j.ajpb.20170204.11 
20. Das C, Dey A, Bandyopadhyay A. Allelochemicals: an emerging tool for weed management. In: Mandal SC, Chakraborty R, Sen S, editors. Evidence based validation of traditional medicines. Singapore: Springer; 2021. p. 249-59. doi: 10.1007/978-981-15-8127-412

21. Negishi N, Nakahama K, Urata N, Kojima M, Sakakibara H, Kawaoka A. Hormone level analysis on adventitious root formation in Eucalyptus globulus. New Forests. 2014 Jul;45(4):577-87. doi: 10.1007/s11056-014-9420-1

22. Abd El-Azeem MS, Hassan HMS, Abdallah SAS. In vitro propagation of Eucalyptus citriodora plant. Future J Biol. 2019 Oct;3:34-43.

23. Bispo EF, Meneses NB, Sousa GO, Sousa FARM, Costa EBS. Allelopathic effect of aqueous extract of Cyperus rotundus on Lactuca sativa and Solanum lycopersicum. Científica. 2020 Oct;48(1):36-40. doi: 10.15361/1984-5529.2020v48n1p36-40

24. Scariot E, Bonome LTS, Bittencourt HVH, Lima CSM. Extrato aquoso de Cyperus rotundus no enraizamento de estacas lenhosas de Prunus persica cv. 'Chimarrita'. Rev Ci Agrovet. 2017;16(2):195200. doi: $10.5965 / 223811711622017195$

25. De Oliveira Junior JC, Rodrigues MCS, Oliveira E, de Souza FML. Enraizamento de handroanthus chrysotrichus (mart. Ex dc.) Via miniestaquia sob diferentes dosagens do extrato de cyperus rotundus. Braz J Develop. 2020 Dec;6(12):102703-13. doi: 10.34117/bjdv6n12-676

26. Thiesen LA, Schmidt D, Holz E, Altissimo BS, Pinheiro MVM, Holz E. Viabilidade do extrato aquoso de Cyperus rotundus como indutor de enraizamento em estacas de videira em comparação com hormônios sintéticos. Acta Biol Catarinense. 2019 Jul-Set;6(3):14-22. doi: 10.21726/abc.v6i3

27. Delazeri P, Barbieri G, Garlet J. Impacts of different phytohormones on the vegetative propagation of seedlings of Eucalyptus dunnii Maiden and Eucalyptus badjensis Beuzev \& Welch. Aust J Basic \& Appl Sci. 2017 Jun;11(9):105-10.

28. Ferreira DF. A computer statistical analysis system. Ciênc. Agrotec. 2011 nov/dez;35(6):1039-42.

29. Rezende FPF, Zuffellato-Ribas KC, Koehler HS. Aplicação de extratos de folhas e tubérbulos de Cyperus rotundus L. e de auxinas sintéticas na estaquia caulinar de Duranta repens L. Rev Bras Plantas Med. 2013;15:639-45. doi: 10.1590/S1516-05722013000500003

30. Pandey D, Pathak RK. Biochemical basis of rooting potentiality in apple hard wood cuttings ii-rooting cofactors and inhibitors. Indian J Horticulture. 1981;38(3and4);171-7.

31. Rocha FG, de Mello Brandenburg M, Pawloski PL, da Silva Soley B, Costa SCA, Meinerz CC, et al. Preclinical study of the topical anti-inflammatory activity of Cyperus rotundus L. extract (Cyperaceae) in models of skin inflammation. J ethnopharm. 2020;254:112709. doi: 10.1016/j.jep.2020.112709

32. Dias JRM, Silva EA, Gonçalves GS, Silva JF, Souza EFM, Ferreira E, et al. Enraizamento de estacas de cafeeiro imersas em extrato aquoso de tiririca. Coffee Sci. 2012 Sep;3(7):259-66.

33. Coltro S, Viecelli CA, Broetto L, Salibe AB, Silva CTC, Rodrigues TRD. Enraizamento de estacas de videira IAC 313 por extratos de tiririca (Cyperus rothundus). Cad Agroecol. 2011 Dec, 2(6):1-4.

34. Souza MF, Pereira EO, Martins MQ, Coelho RI, Pereira-Junior OS. Efeito do extrato de Cyperus rotundus na rizogênese. Rev Ciênc Agr. 2012 Jan;15(35):157-62.

35. Rezende FPF, Zeffellato-Ribas KC, Koehler HS. Aplicação de extratos de folhas e de tubérculos de Cyperus rotundus L. e de auxinas sintéticas na estaquia caulinar de Duranta repens L. Rev Bras Pl Med. 2013;4(15):639-45. doi: 10.1590/S1516-05722013000500003

36. da Costa CT, de Almeida MT, Ruedell CM, Schwambach J, Maraschin FS, Fett-Neto AG. When stress and development go hand in hand: main hormonal controls of adventitious rooting in cuttings. Front Plant Sci. 2013;4(133):1-19. doi: 10.3389 / fpls.2013.00133

37. Pacurar DI, Perrone I, Bellini C. Auxin is a central player in the hormone cross talks that control adventitious rooting. Physiol Plant. 2014 May;1(151):83-96. doi: 10.1111/ppl.12171

38. Goulart PB, Xavier A, Cardoso NZ. Efeito dos reguladores de crescimento AIB e ANA no enraizamento de miniestacas de clones de Eucalyptus grandis X Eucalyptus urophylla. Árvore. 2008 Aug;6(32):10518. doi: $10.1590 / \mathrm{S} 0100-67622008000600010$

39. Câmara FMM, Carvalho S, Mendonça V, Paulino RC, Diógenes FEP. Sobrevivência, enraizamento e biomassa de miniestacas de aceroleira utilizando extrato de tiririca. Comun Sci. 2016 Oct;7(1):133-8. doi: $10.14295 /$ CS.v7i1.1372

40. Silva CTAC, Alves Neto AJ, Viecelli CA. Extratos aquosos de tiririca sobre o enraizamento de canade-açúcar. Varia Sci Agr. 2011 Dec;2(1):49-61

41. Azevedo HPA, Carvalho, AM, Vidal DA, Santos HO, Doria J. Rooting biostimulants for Coffea arabica L. cuttings. Coffee Sci. 2020 Jun;15:e151635. doi: 10.25186/cs.v15i.1635 